\title{
Upper Clivus Meningioma
}

National Cancer Institute

\section{Source}

National Cancer Institute. Upper Clivus Meningioma. NCI Thesaurus. Code C5290.

A meningioma that affects the upper clivus. 